\title{
柑㰌の結果枝短截(二度切り)の不利に就て*
}

\author{
岩㣛藤助

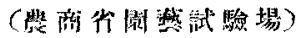

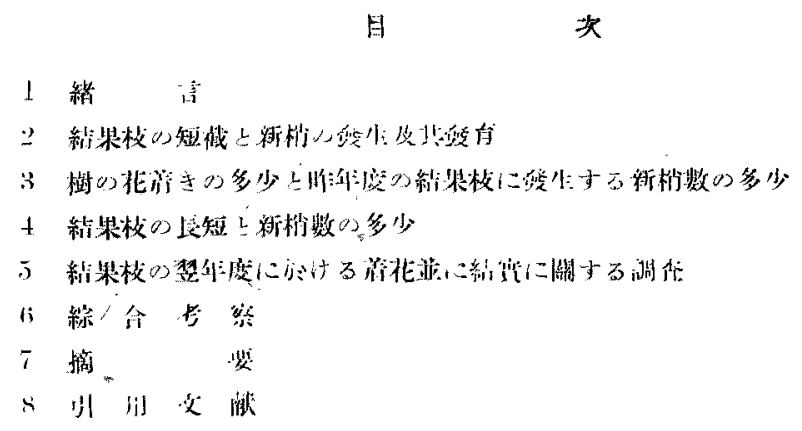

1. 緒式

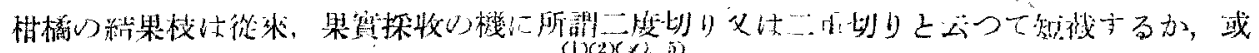

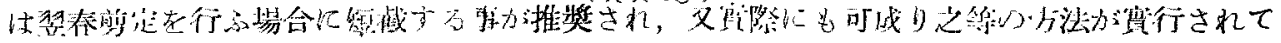

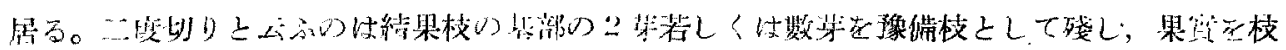

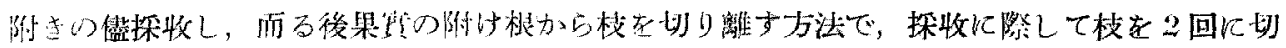

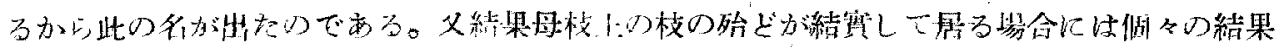

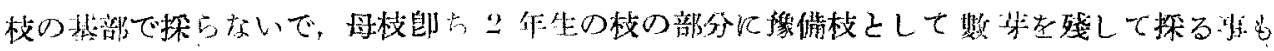

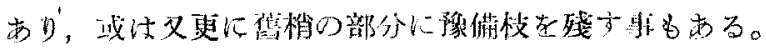

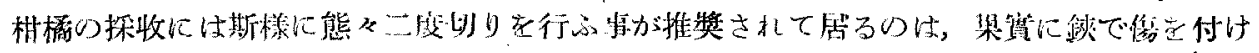

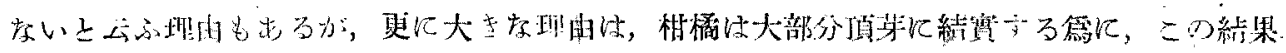

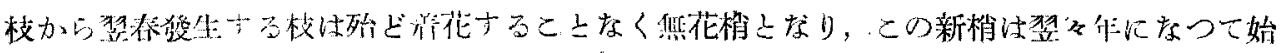

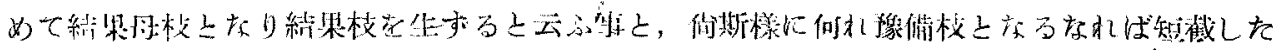

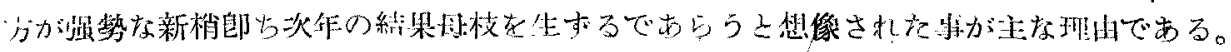

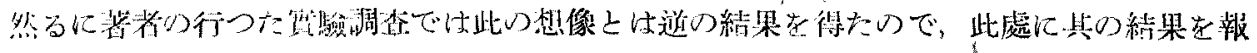

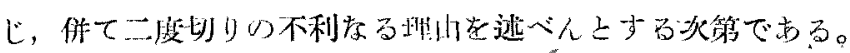

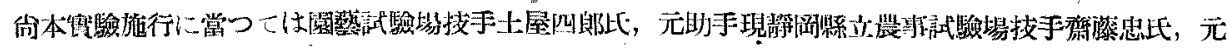

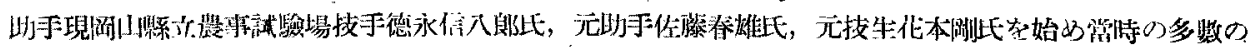

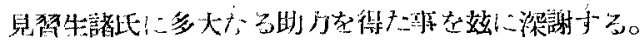

\section{2. 結果枝の短截已新梢の發生及其墢育}

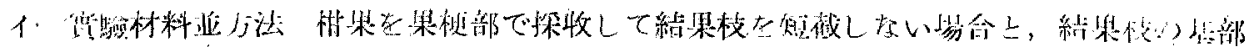

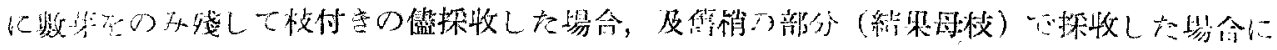

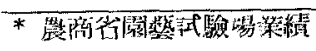




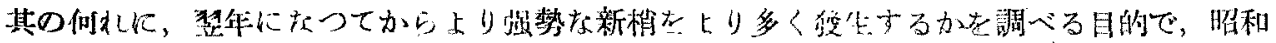

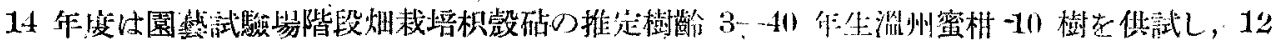

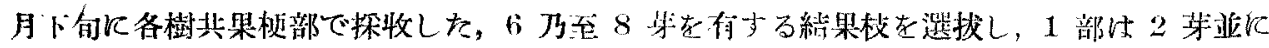

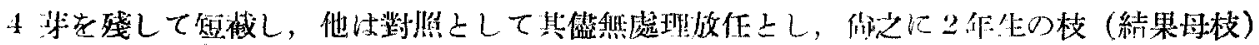

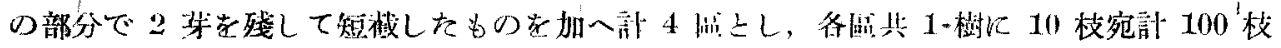

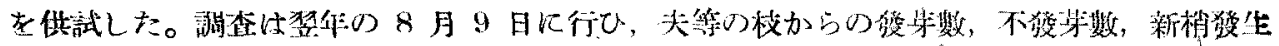

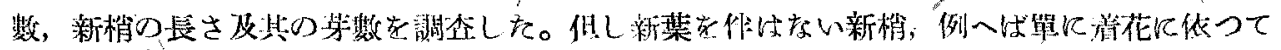
生じを构短小を新椎は除外した。以下问。

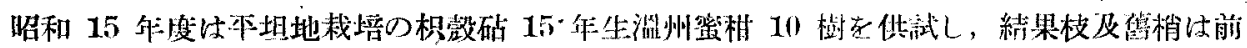

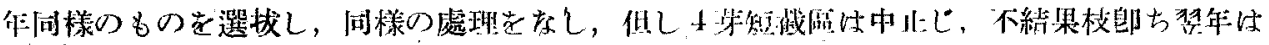

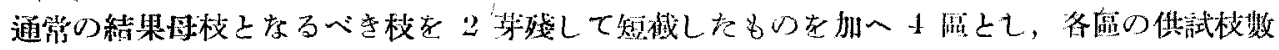

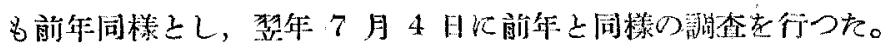

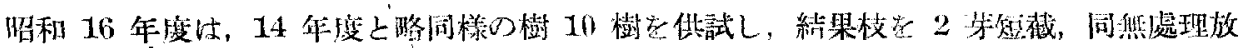

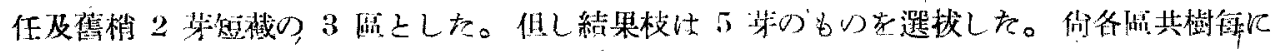

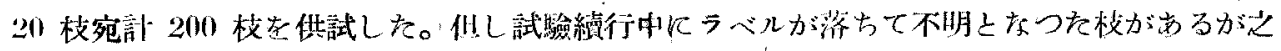

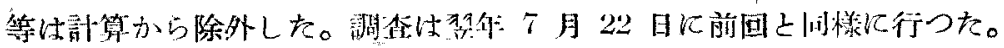

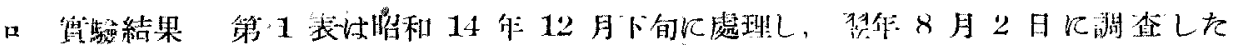

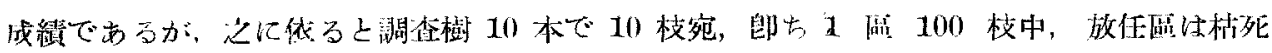

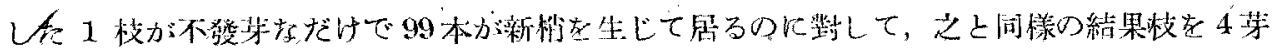

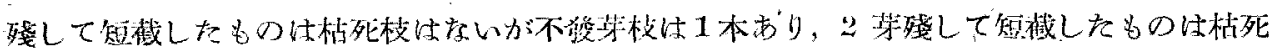

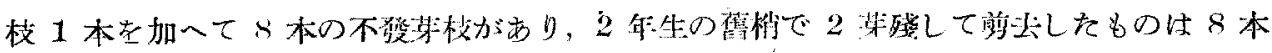

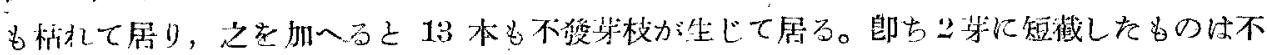

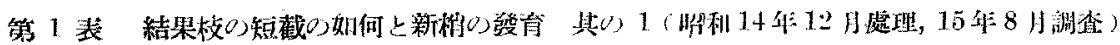

\begin{tabular}{|c|c|c|c|c|c|c|c|c|c|c|c|}
\hline " & 偝 & 摆 & 解 & 菒 & 枯 & 洲 & 查 校 & 隹 & 㙰** & 新梢，代筈 & 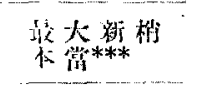 \\
\hline 别 & 粨 & 校 & 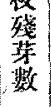 & 萎 & 校 & 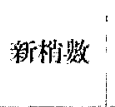 & 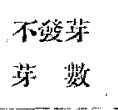 & $\begin{array}{l}\text { 彩梢延 } \\
\text { 这(枉) }\end{array}$ & $\begin{array}{l}\text { 洲 梢 } \\
\text { 延芽残 }\end{array}$ & 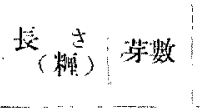 & 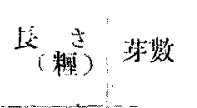 \\
\hline 放 任 皿 & 10 & 100 & 7 & 1 & 1 & $4.8 \pm 0.2$ & $3.8 \pm 0.1$ & $45 \pm 1.9$ & $30 \pm 1.2$ & $10 \pm 0.5 ; 6 \pm 0.2$ & $14 \pm 0.6 \quad 8 \pm 0.2$ \\
\hline 4 宾短截险 & 10 & 100 & 4 & 1 & 0 & $2.9 \pm 0.1$ & $1.9 \pm 0.1$ & $26 \pm 1.7$ & $17 \pm 0.6$ & $9 \pm 0.56 \pm 0.2$ & $11 \pm 0.67 \pm 0.2$ \\
\hline 2 芽短截澡 & 11 & 100 & 2 & 8 & 1. & $1.5 \pm 0.1$ & $0.8 \pm 0.1$ & $13 \pm 0.8$ & $9 \pm 0,0$ & $9 \pm 0.50 \pm 0.1$ & \\
\hline 蕉梢短㭖厤 & 10 & 1100 & 2 & 13 & 8 & $1,6 \pm 0,1^{1}$ & $0.7 \pm 0.1$ & $10 \pm 0.7$ & $7 \pm 11.3$ & $6 \pm 0.3: 4 \pm 0.1$ & \\
\hline
\end{tabular}

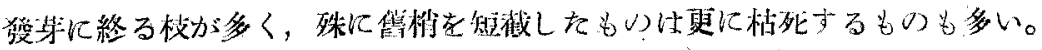

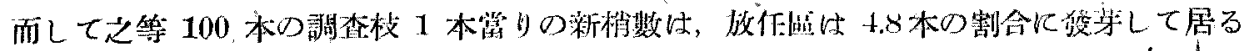

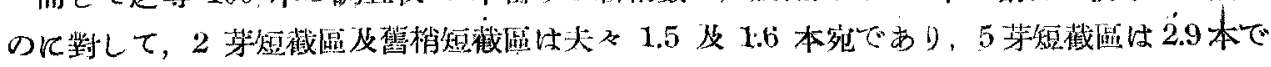

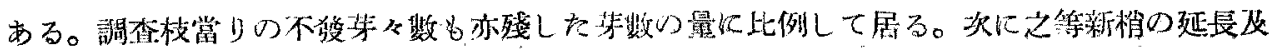

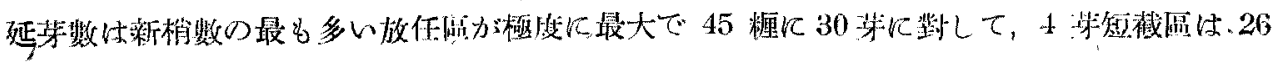




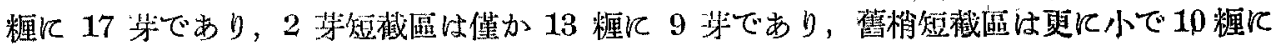
7 犽で离る。

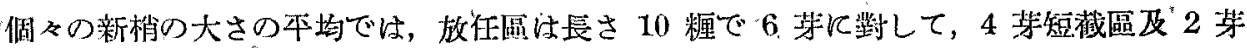

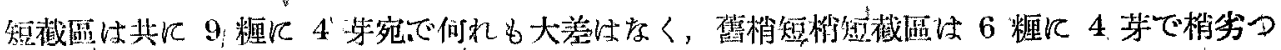

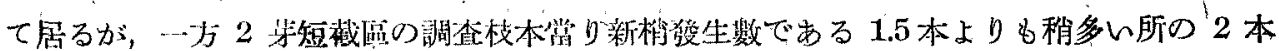

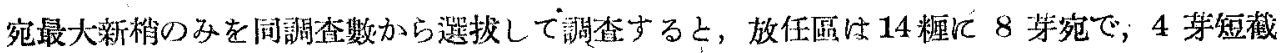
區は 11 糎に 7 紫であつて，明に大なる新梢老生じて居る。

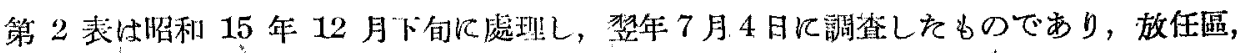

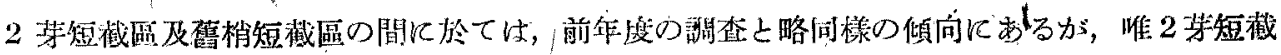

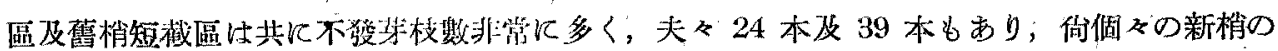

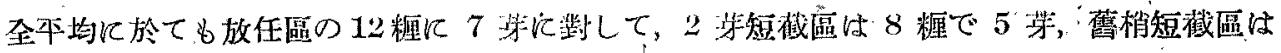
6 糎で 5 讶亡共化明劣つて居る。

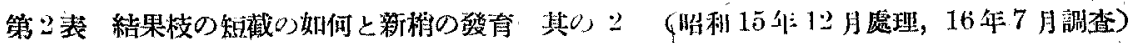

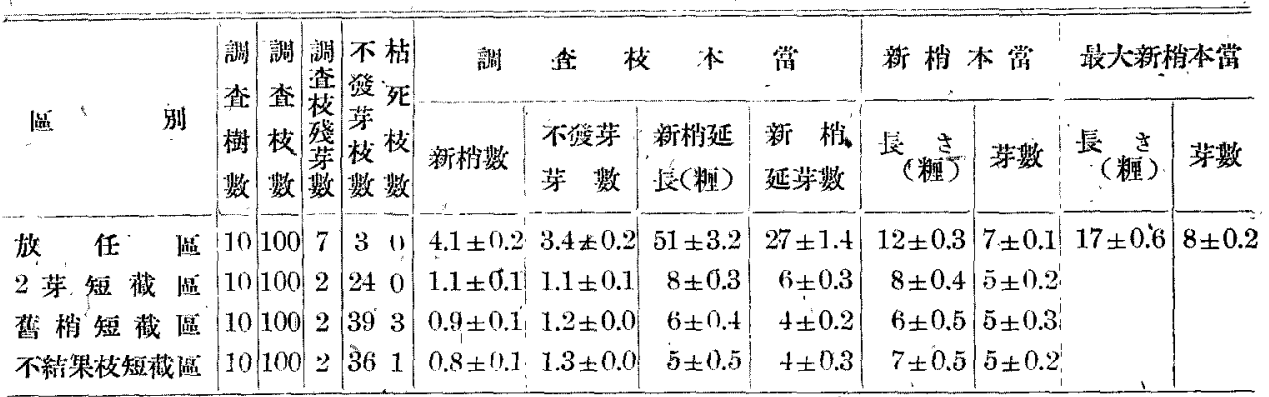

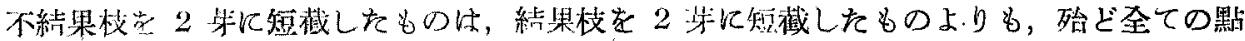
に於て劣り，舊梢で短截した它のと大凡比適して居る。

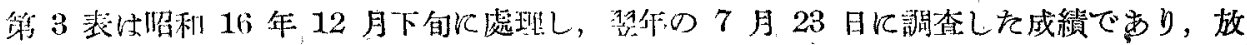

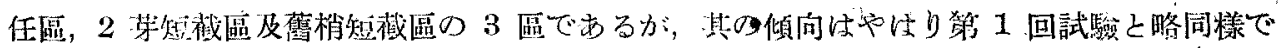

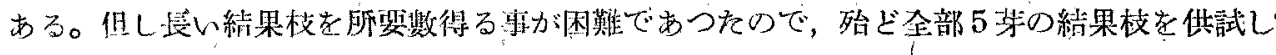

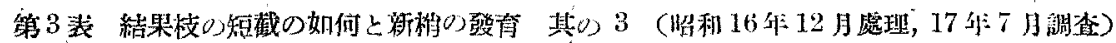

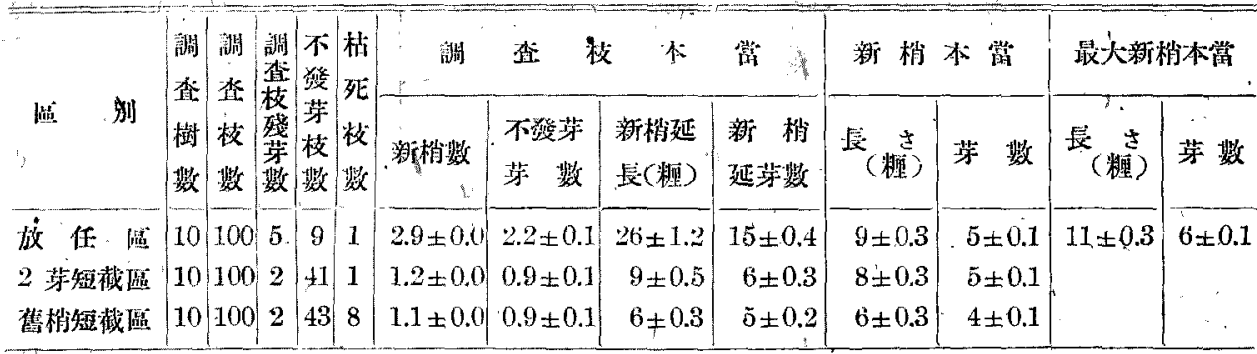

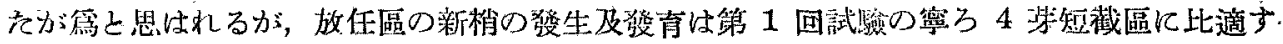

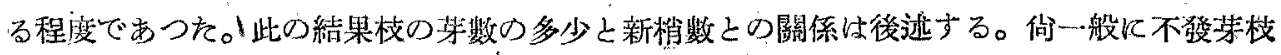
が多く，殊飞 2 第及舊梢短截區に多汃つた。 


\section{3. 樹の花着きの多少と昨年度の結果枝に發生する新梢數の多少}

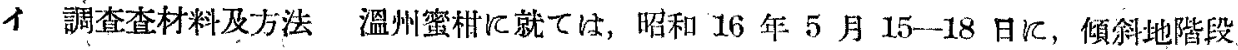

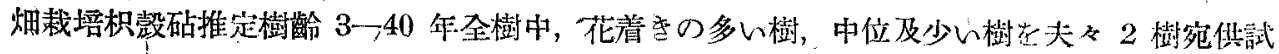
し，前年度の結果枝に發生して居る新梢數調查した。

份同月 18 日に，枳殼砧 38 年生ワシントン・ネーブル・オレンヂの花着きの稍多い樹と

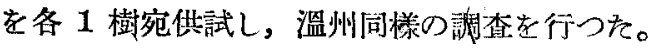

第士 表 溫州蜜柑花䄍きの多少と結果枝 上穴新梢數（昭和 16 年 5 月）

\begin{tabular}{|c|c|c|c|c|c|}
\hline \multicolumn{2}{|c|}{ 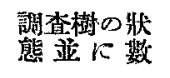 } & $\begin{array}{l}\text { 紡果枝 } \\
\text { の新数 }\end{array}$ & $\begin{array}{l}\text { 請 } \\
\text { 校 } \\
\text { 剩 }\end{array}$ & $\begin{array}{l}\text { 季 祅* } \\
\text { 全 数 }\end{array}$ & 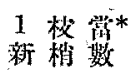 \\
\hline \multirow{5}{*}{ 花着 } & \multirow{5}{*}{$\begin{array}{c}\text { 少量樹 } \\
2 \text { 本 }\end{array}$} & $1-3$ & 102 & 140 & 1.4 \\
\hline & & $4-6$ & 212 & $570^{\circ}$ & 2.7 \\
\hline & & $7-9$ & 76 & 349 & 4.6 \\
\hline & & $10-12$ & 10 & 49 & 4.9 \\
\hline & & 部 & 400 & 1108 & $2.8 \pm 0.06$ \\
\hline \multirow{5}{*}{ 花莣 } & \multirow{5}{*}{$\begin{array}{c}\text { 中位樹 } \\
2 \text { 本 }\end{array}$} & $1-3$ & 85 & 137 & 1.6 \\
\hline & & $4-6$ & 200 & 538 & 2.7 \\
\hline & & $7-9$ & 68 & 290 & \\
\hline & & $10-12$ & 7 & 37 & 5.2 \\
\hline & & 計 & 360 & 1002 & $2.8 \pm 0.06$ \\
\hline \multirow{5}{*}{ 花着 } & \multirow{5}{*}{$\begin{array}{l}\text { 多量樹 } \\
2 \text { 本 }\end{array}$} & $1-3$ & 109 & 141 & 1.3 \\
\hline & & $4-6$ & 201 & 488 & 2.4 \\
\hline & & $7-9$ & 66 & 237 & 3.6 \\
\hline & & $10-12$ & 4 & 23 & 5.8 \\
\hline & & 計 & 380 & 889 & $2.3 \pm 0.06$ \\
\hline
\end{tabular}

* 無新葉新梢老除

第5表 ワシントシ・ネーブル・オレンデ樹の 花静きの多少と結果枝上の新䊑數 (骠利 16 年 5 月)

\begin{tabular}{|c|c|c|c|c|}
\hline 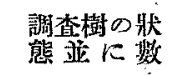 & 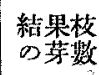 & 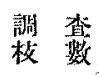 & $\begin{array}{l}\text { 新 梢** } \\
\text { 全 数 }\end{array}$ & $\begin{array}{l}1 \text { 校监* } \\
\text { 新梢数 }\end{array}$ \\
\hline \multirow{5}{*}{$\begin{array}{r}\text { 北着稍少量樹 } \\
1 \text { 本 }\end{array}$} & & 72 & 67 & 0.9 \\
\hline & $4-$ & 101 & 196 & 1.9 \\
\hline & $7-9$ & 23 & 80 & 3.5 \\
\hline & $10-12$ & 4 & 18 & 4.5 \\
\hline & & 200 & 361 & $1.8 \pm 0.07$ \\
\hline \multirow{5}{*}{$\begin{array}{c}\text { 托清稍多量樹 } \\
1 \text { 本 }\end{array}$} & & 34 & 47 & 1. \\
\hline & $4-6$ & 79 & 150 & 1.9 \\
\hline & $7-9$ & 14 & 38 & 2.7 \\
\hline & $10-12$ & 3 & 18 & 6.0 \\
\hline & 棓 & 130 & 253 & $1.9 \pm 0.08$ \\
\hline
\end{tabular}

* 無新耗新梢を除?

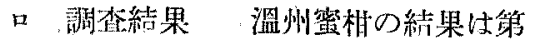
4 荎の如くでめり，之垈る上，花着き の少い樹で壮調查結果枝 400 枝で 1108

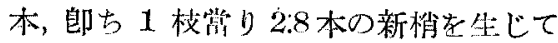
庫り，花着きの中位の樹㤌 360 忮で新杪 1002 本, 郎占 1 玟嫦りは卢はり 2.8 本 であり，花着きの多い樹では 380 枝で 889 本の新梢老生し；1 枝當りは 2.3 本 である。即ち花着きの多い樹结絬果枝に 生ずる新梢數が幾分かげ少いが大差で㤌 算的。

ワシントン・ネーブル・オレンヂの結果 は第 5 表の通りであつて，大體の傾向は 溫州蜜相々略同樣である。郎ち花着をの 稍少い樹结 200 本の調查枝で 360 本の

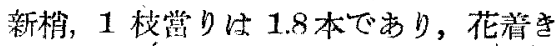
の多い樹では 130 枝で 253 本，1 枝賞 りは 1.9 本であつて，雨者の間长差は 無い。

\section{4. 結果枝の長短と新梢數の多少}

1 調查材料並方法 昭和 16 年溫 州蜜柑及ワシントン・ネーブルーナレンヂ 共に花着要の多少上新梢數之の關係を詷” べる上同時に同一樹に就て, 結果枝の長 短 (㧎數の多少) 之新梢數の多少之の關 係老詞盉して。

口 調查緹果溫州蜜湘の結果岋第 6 表の如くであり，(第 4 表參照) 1 乃至 9 芽枝及 10 芽以上（10-12 芽) 枝區怙， 夫心 1 枝掌り $0.9,1.2,1.6,2.0,2.7$, $3.3,33.8,4.3,5.1$ 及 5.2 本心新祅老㷋生. 


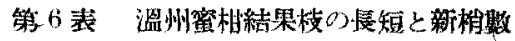

(昭利 16 年:5月)

\begin{tabular}{|c|c|c|c|c|c|}
\hline \multirow{2}{*}{ 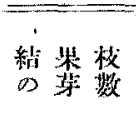 } & \multirow{2}{*}{ 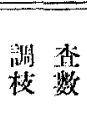 } & \multicolumn{2}{|c|}{ 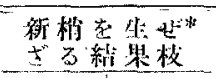 } & \multicolumn{2}{|c|}{ 精 䊑 } \\
\hline & & 枝 数 & $=(0,0)$ & 企數 & 1 极需*** \\
\hline 1 & 27 & it & $\because 2$ & 24 & $0.9 \pm 0.08$ \\
\hline 2 & 69 & $1+$ & 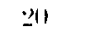 & 80 & $1.2 \pm 0.066$ \\
\hline 3 & 200 & 涼 & 18 & 314 & $1.6 \pm 0.05$ \\
\hline 4 & 2839 & 25 & 10 & +83 & $2.0 \pm 0.05$ \\
\hline 5 & 203 & 8 & + & 551 & $\because 7 \pm 0.06$ \\
\hline 6 & $j 71$ & (1) & - & 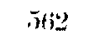 & $3.3 \pm 0.09$ \\
\hline 7 & 110 & 0 & - & +17 & $3.8 \pm 0.10$ \\
\hline 8 & 65 & 0 & - & 282 & $4.3 \pm 0.17$ \\
\hline 9 & 35 & 0 & - & 177 & $5.1 \pm 0.20$ \\
\hline 10 以上*** & 21 & 0 & - & 109 & $5.2 \pm 0.32$ \\
\hline 矿 & $11+0$ & 88 & 8 & 2999 & $2.6 \pm 0.04$ \\
\hline
\end{tabular}

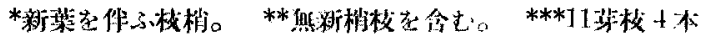
及 12 荡校 3 㓅を会む

第7表 ワシントン・ネーブル・オレンヂ結果

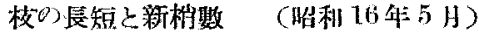

\begin{tabular}{|c|c|c|c|c|c|}
\hline \multirow{2}{*}{$\begin{array}{l}\text { 粘果枝 } \\
\text { の芽數 }\end{array}$} & \multirow{2}{*}{$\begin{array}{l}\text { 㒛查 } \\
\text { 校卙 }\end{array}$} & \multicolumn{2}{|c|}{ 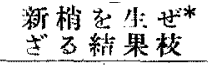 } & \multicolumn{2}{|c|}{ 欶 梢 数* } \\
\hline & & 校- 数 & 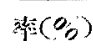 & 金数 & 1 板雷** \\
\hline 1 & 15 & 8 & 53 & 7 & $0.5 \pm 0.01$ \\
\hline 2 & 37 & 10 & 27 & 34 & $0.9 \pm 0.01$ \\
\hline 3 & 54 & 10 & 19 & -73 & $1.4 \pm 0.01$ \\
\hline 4 & 66 & 13 & 20 & 109 & $1.7 \pm 0,01$ \\
\hline 5 & 75 & 8 & 11 & $1+5$ & $1.4 \pm 0.01$ \\
\hline 6 & 39 & 3 & 8 & 92 & $2.4 \pm 0.02$ \\
\hline 7 & 24 & 1 & $t$ & sit & $2.7 \pm 0.03$ \\
\hline 8 & 9 & 0 & -1 & 36 & $4.0 \pm 0.03$ \\
\hline 9 & 4 & 0 & $\ldots$ & 18 & $4.5 \pm 0.0 .3$ \\
\hline 10以上**** & 7 & 0 & - & 36 & 5. $1 \pm 0.014$ \\
\hline it & 330 & 53 & 16 . & 614 & $1.4+0.05$ \\
\hline
\end{tabular}

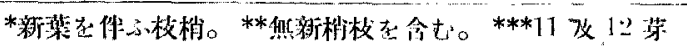
校各 1 水を含志，
してて居り，䋨果枝の芽數の多い者程 多潄の新梢 -發生して居る。而して

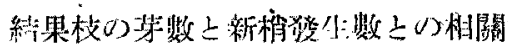

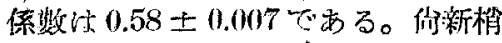

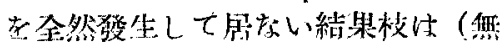

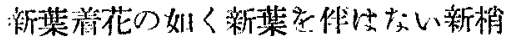
除〈） 1 万至 万第區で夫其の ' $22,18,10,40$ 名新梢を生じて居 ら声，6第枝以上は全部新悄を生じ て居る。郎ち睪数の少い者程新梢を 破生し标い枝为多い。

ワシントン・ホーブル・オレンヂの

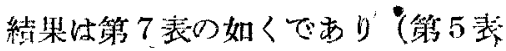
參㷛）其の傾问は溫州之问樣㫮数の 多、紹果枝程多くの新梢在發生して 属り，逆儿些數の少い絬果枝程䉼梢 を發生しない枝が多い。郎ち1乃至 9 芽枝及 10 第以上枝仕夫《 1 枝當 り $0.5,0.9,1.4,1.7,1.9,2.4,2,7$; $4.0,4.5$ 及 5.1 本の新窎学發生して 居り，結果枝の年数之新梢㟋生數之

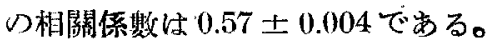
热新梢結果枝法 1 乃系 7 第校で， 夫《 $53,27,14,20,11,8$ 及 $4 \%$ でする。

\section{5. 結果枝の翌年度に於ける着 花並に結實に閣与る調查}

1 淍查材料证方法。結果枝注 想作には全然湆花し，存い为のか，或 は蟣揢加洋花するものであるが

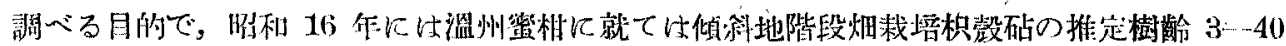

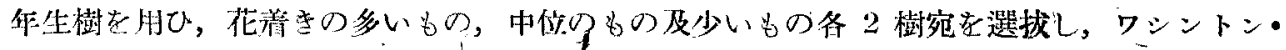

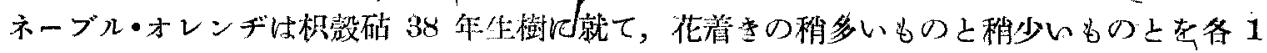

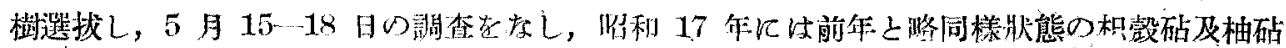

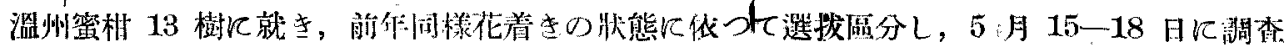

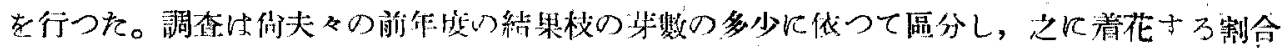
及其の量䘮調べ地。

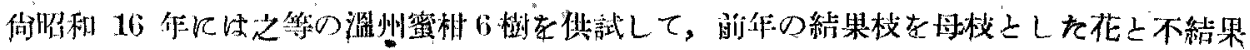


枝を母枝とした花とに就て，其の開花の早晚を 5 月 15 日加 6 月13 日飞亘つて調査し， 又之等の花蕾の結實步合に就て 9 月 29 日及 11 月 29 日の 2 回調查をなし，11月30日 マ゙夫ふの果實の重量を測定した。

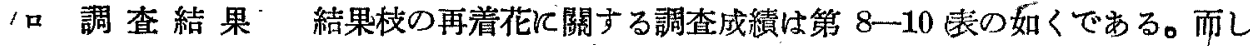
て, 昭和 16 年 5 月 15-18 日飞溫州蜜柑に就て調查した結果性第 8 表の如くである。之 飞依ると前年度の結果枝が再着花する率ほ，花着をの少い樹 2 本の計は結果枝 400 本中の 49 本郎ち $12 \%$ が花蕾を生じて居り，花着き中位の樹は 360 枝中 68 枝郎ち $19 \%$ が花 蕾を生じ，花着きの多い樹では 380 枝中 200 枝郎ち $52 \%$ 多數が花蕾を生じて居り，夫 等 6 樹の全計では $28 \%$ である。

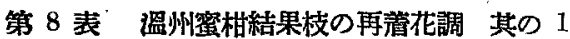

(昭和 16 年 5 月)

\begin{tabular}{|c|c|c|c|c|c|c|}
\hline \multirow{2}{*}{$\begin{array}{l}\text { 調查樹の狀態 } \\
\text { 恶K數 }\end{array}$} & \multirow{2}{*}{$\begin{array}{l}\text { 調查枚 } \\
\text { の荐數 }\end{array}$} & \multirow{2}{*}{ 調棍 } & \multicolumn{2}{|c|}{ 暑花校數 } & \multicolumn{2}{|c|}{ 䈐 花 量 } \\
\hline & & & 花枝数 & 䍩花率 & 全北數 & $\begin{array}{l}\text { 本 賞* } \\
\text { 花 }\end{array}$ \\
\hline \multirow{5}{*}{$\begin{array}{r}\text { 花着少量樹 } \\
2 \text { 本 }\end{array}$} & $1-3$ & 102 & 8 & $\%$ & 9 & 1.1 \\
\hline & $4-6$ & 212 & 24 & 11 & 39 & 1.6 \\
\hline & $7-9$ & 76 & 16 & 21 & 35 & 2.2 \\
\hline & $10-12$ & 10 & 1 & 10 & 2 & 2.0 \\
\hline & 尌 & 400 & 49 & 12 & 85 & 1.7 \\
\hline \multirow{5}{*}{$\begin{array}{r}\text { 花着中位樹 } \\
2 \text { 本 }\end{array}$} & $1-3$ & 85 & 12 & 14 & 16 & 1.3 \\
\hline & $4-6$ & 200 & 40 & 20 & 68 & 1.7 \\
\hline & $7-9$ & 68 & 15 & 22 & 26 & 1.7 \\
\hline & $10-12$ & 7 & 1 & 14 & 3 & 3.0 \\
\hline & 計 & 360 & 68 & 19 & 113 & 1.7 \\
\hline \multirow{5}{*}{$\begin{array}{r}\text { 桃着多量樹 } \\
2 \text { 本 }\end{array}$} & $1-3$ & 109 & 41 & 38 & 65 & 1.6 \\
\hline & $4-6$ & 201 & 118 & 58 & 249 & 2.1 \\
\hline & $7-9$ & 66 & 37 & 56 & 98 & $2.6^{\prime}$ \\
\hline & $10-12$ & 4 & 4 & 100 & 17 & $4.3^{\prime}$ \\
\hline & 計 & 380 & 200 & 52 & 429 & 2.1 \\
\hline \multirow{5}{*}{ 計 6 本 } & $1-3$ & 296 & 61 & 21 & 90 & 1.5 \\
\hline & $4-6$ & 613 & 182 & 30 & 356 & 2.0 \\
\hline & $7-9$ & 210 & 68 & 33 & 159 & 2.3 \\
\hline & $10-12$ & 21 & 6 & 29 . & 22 & 3.7 \\
\hline & 計 & 1140 & 317 & 28 & 627 & 2.0 \\
\hline
\end{tabular}

* 着花新梢を登生せる結果校の本當
佾之を結果枝の苸數の多 少との關係を見ると6 樹の 計で, $1-3$ 芽枝は $21 \%$ 着 花枝索生じて居り，4-6芽 枝は $30 \%, 7-9$ 芽枝は 33 \%, 10-12 芽枝は $29 \%$ が 夫ふ着花枝を生じて居る。 而して侣樹の花着きの多少 之其の樹々の結果枝の長短 とを見比べると；何れの樹 \& 7-9 芽枝が着花最大で, 芽数の少い枝郎台短い枝程 着花率は低下して居る。但 し 10 芽以上の枝は數少く 確な事は不明であるが，花 着きの多い樹では 2 枝宛計 4 本加全部着花して居るの 之, 花着きの中位の樹中の 1 樹がやはり最大であるが， 他の 3 樹は 7-9 芽枝より も劣つて居る。

之等再着花した結果枝の 1 枝當りの花蕾數证，樹の 花着きの多少飞依つて忙大 差はなく，即占花青きの少いるの及中位のbのは共に 1.7 個で，多い樹のみが 2.1 個である が，結果枝の芽數の多少飞依つては大差があり，郎ち 1-3 芽枝は 1.5 個，4-6芽枝は 2.0 個，7-9 芽枝は 2.3 個，10-12 第枝は３.7 倜で，其の全本均は 2.0 個である。而して唯 1 つの例外の他㤬全樹悉く隻い枝程花數が多く，結果枝の芽數之着花量とは正比例して居る。

第 9 表壮昭和 17 年 5 月 15-18 日に調查せる成續である。而して其の続果は樹の花亚 の狀態並に前年度の結果枝の長短に依る，着花新梢の發生具合の大體の傾向は前年度の結 
第 9 等 溫州蜜相結果枝の再静花調 其の 2 (昭和 17 年 5 月)

\begin{tabular}{|c|c|c|c|c|c|c|}
\hline \multirow{2}{*}{ 諴查樹の狀態並に數 } & \multirow{2}{*}{$\begin{array}{l}\text { 筬查枝 } \\
\text { 芽数 }\end{array}$} & \multirow{2}{*}{ 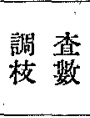 } & \multicolumn{2}{|c|}{ 算”花校 数 } & \multicolumn{2}{|c|}{ 着， 花 量 } \\
\hline & & & 花校数 & 着花被 & 全花数 & $\begin{array}{l}\text { 本 當* } \\
\text { 薮 }\end{array}$ \\
\hline & $1-3$ & 332 & 24 & \% & 35 & 1.5 \\
\hline 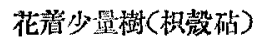 & $4-6$ & 164 & 15 & 9 & 30 & 2.0 \\
\hline \multirow[t]{2}{*}{2 本 } & $7-9$ & 9 & 1 & 11 & 3 & 3.0 \\
\hline & 䚵 & 505 & 40 & 8 & 68 & 1.7 \\
\hline & $1-3$ & 201 & 28 & 14 & 43 & 1.5 \\
\hline 花着㮐少樹(枳殼砧) & $4-6$ & 74 & 10 & 14 & 18 & 1.8 \\
\hline \multirow[t]{2}{*}{2 本 } & $7-9$ & 4 & 2 & 50 & 2 & 1.0 \\
\hline & 計 & 279 & 40 & 14 & 63 & 1.5 \\
\hline i & $1-3$ & 277 & 78 & 28 & 112 & 1.5 \\
\hline 花着中位樹(积款砧) & $4-6$ & 115 & 51 & 44 & 97 & 1.9 \\
\hline \multirow[t]{2}{*}{2 本 } & $7-9$ & 11 & 5 & 45 & 9 & 1.8 \\
\hline & 計 & 403 & 134 & 33 & 218 & 1.6 \\
\hline \multirow{4}{*}{$\begin{array}{c}\text { 花籍多量樹(枳豰砧) } \\
3 \text { 本 }\end{array}$} & $1-3$ & 258 & 130 & 50 & 278 & 2.1 \\
\hline & $4-6$ & 191 & 133 & 70 & 482 & 3.7 \\
\hline & $7-9$ & 27 & 23 & 85 & 167 & 7.3 \\
\hline & 計 & 476 & 286 & 60 & 927 & 3.2 \\
\hline \multirow{4}{*}{$\begin{array}{c}\text { 积破 } \\
9 \text { 本 }\end{array}$} & $1-3$ & 1068 & 260 & 24 & 468 & 1.8 \\
\hline & $4-6$ & 544 & 209 & 38 & 627. & 3.0 \\
\hline & $7-9$ & 51 & 31 & $6 \mathrm{I}$ & 181 & 5.8 \\
\hline & 計 & 1663 & 500 & 30 & 1276 & 2.6 \\
\hline \multirow{4}{*}{$\begin{array}{c}\text { 扎萻中位樹(柏砧) } \\
4 \text { 本 }\end{array}$} & $1-2$ & 390 & 58 & 15 & 72 & 1.2 \\
\hline & $4-6$ & 197 & 53 & 27 & 88 & 1.7 \\
\hline & $7-9$ & 13 & 5 & 38 & 11 & 2.2 \\
\hline & 計 & 600 & 116 & 19 & 171 & 1.5 \\
\hline
\end{tabular}

* 着挑新梢雚生せる結果校の本虽

果之略同樣でるる か，唯其の差晎为: 層顯著である。郎ら 前年度の結果枝が再 着花する率恃，积款 砧で注花着きの少い 粠で $8 \%$, 稍少、樹 で 14\%，中位の樹 で $33 \%$, 多量樹で忧 $60 \%$ であり,其の綜 計では結果枝 1663 枝中 500 枝为洋花し て居り $30 \%$ 飞相虽 する。柚砧仕花着要 中程度の樹のみ 4 本 であるが，緿果枝 600 本中 116 本が着 花し $19 \%$ である。

而して結果枝の長 短飞体る差異柱枳殼 砧 9 本の綜計怔， 1 -3 芽枝住 $24 \%, 4$ -6 芽枝仕 $38 \%, 7$ -9 芽枝は $61 \%$ で あり，柚砧地夫夫 $15 \%, 27 \%$ 及 $38 \%$ である。但し柚砧も

枳款砧の花着きの中位の樹と此べると左程の大差はない。

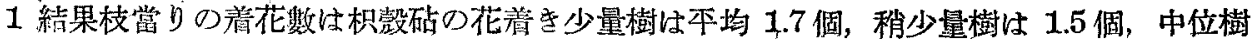
は 1.6 個であり，柚砧も本均 1.5 個で大差はないが，枳款砧の花着き多量樹のみ社 3.2 個で 可成り多量に着花して居る。

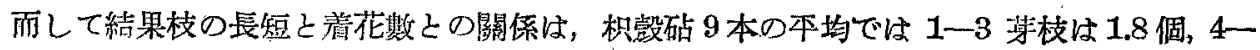

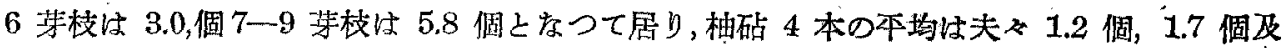
2.2 個であり，何れ多結果枝の長さに比例して多〈なつて居る。

第 10 表は昭和 16 年 5 月 18 日に調查せるワシントン・ネーブル・オレ゙ンデの結果であ る。之に依るとワシントン・ネーブル再着花するものは非常に少く，郎ち花着きの稍少い

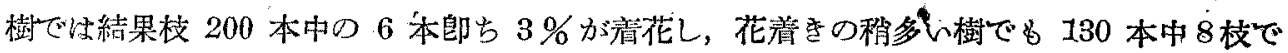
$6 \%$ 亿過ぎす，其の本均计 $4 \%$ である。

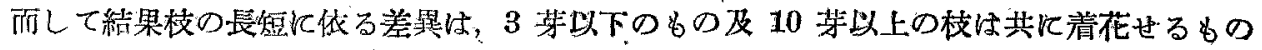


なく，4-6 等枝及 $7-9$ 枝のものが $16 \%$ 宛着花 して居る。次着花新梢 を發生して居る結果枝の 本當り花數は全平均飞於 て 2.3 個である。

前年の結果枝を母枝と した花と, 不結果枝 (本 年は本來乍らの母枝之な るべを枝）を母枝とした 花との開花の早晚に關す る調查成績は第 11 表的 示す如くであり, 本調查 は昭和 16 年の成績で, 全區を通じて開花始的は 5 月 15 日で, 最終日は 6 月 13 日である。

而して昨年の不結果枝 を母枝とした花の開花日 は綜平均飞於 $\tau$ ，新葉加發生 して居るものも 新葉のないもの も共化 5 月 23 日であるのに對 して，昨年の結 果枝を母枝とし た花沬 5 月 27 日であり，綜じ て4日間晚れて 居り，台花着き の多少飞依る各 樹間の傾向当何 れ女 3 - 5 .日宛 晚れて居る。佾
第10表 ネーブル・オレンデの結果枝の再着花調

(昭利 16 年 5 月)

\begin{tabular}{|c|c|c|c|c|c|c|}
\hline \multirow{2}{*}{$\begin{array}{l}\text { 開査樹 の } \\
\text { 狀態亚に數 }\end{array}$} & \multirow{2}{*}{ 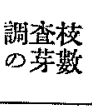 } & \multirow{2}{*}{ 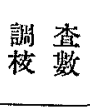 } & \multicolumn{2}{|c|}{ 族花校数 } & \multicolumn{2}{|c|}{ “盖 花 量 } \\
\hline & & & $\begin{array}{l}\text { 本 譡* } \\
\text { 花 數 }\end{array}$ & 筧花栓 & 全花數 & 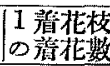 \\
\hline \multirow{5}{*}{ 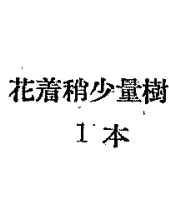 } & $1-3$ & 72 & 0 & $0^{\circ}$ & 0 & - \\
\hline & $4-6$ & 101 & 5 & 5 & 12 & 2 \\
\hline & $7-9$ & 23 & 1 & 4 & 7 & 7 \\
\hline & $10-12$ & 4 & 0 & 0 & 0 & - \\
\hline & 計 & 200 & 6 & 3 & 19 & 3 \\
\hline \multirow{5}{*}{$\begin{array}{c}* \\
\text { 花滔稍多量樹 } \\
1 \text { 本 }\end{array}$} & $1-3$ & 34 & 0 & 0 & 0 & - \\
\hline & $4-6$ & 79 & 4 & 5 & 4 & 1 \\
\hline & $7-9$ & 14 & 4 & 29 & 9 & 2 \\
\hline & $10-12$ & 3 & 0 & 0 & 0 & - \\
\hline & 計 & 130 & 8 & 6 & 13 & 2 \\
\hline \multirow{5}{*}{$\begin{array}{l}\text { 計 } \\
2 \text { 本 }\end{array}$} & $1-3$ & 106 & 0 & 0 & 0 & - \\
\hline & $4-6$ & 180 & 9 & 5 & 16 & 2 \\
\hline & $7-9$ & 37 & 5 & 14 & 16 & 3 \\
\hline & $10-12$ & 7 & 0 & 0 & 0 & - \\
\hline & 計 & 330 & 14 & 4 & 32 & 2.3 \\
\hline
\end{tabular}

**着花新梢孝登生せる結果枝の本虽

第 11 表 溫州蜜柑再菁花校の開花の早晚（昭和 16 年5-6月）

\begin{tabular}{|c|c|c|c|c|c|c|}
\hline \multirow{2}{*}{ 區 } & \multirow{2}{*}{ 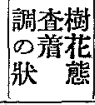 } & \multirow{2}{*}{$\begin{array}{l}\text { 調查 } \\
\text { 樹 數 }\end{array}$} & \multirow{2}{*}{$\begin{array}{l}\text { 謂 查 } \\
\text { 校数 }\end{array}$} & \multirow{2}{*}{$\begin{array}{l}\text { 拥查 } \\
\text { 花数 }\end{array}$} & \multicolumn{2}{|c|}{ 花 } \\
\hline & & & & & 本均月目 & 殹笓㣂养 \\
\hline \multirow{4}{*}{ 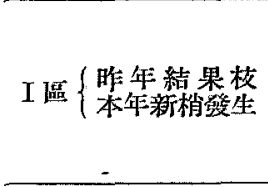 } & 少量 & 2 & 65 & 121 & $5,28 \pm 0.30$ & $\pm 0.45 \pm 0.020$ \\
\hline & 中位 & 2 & 65 & 125 & $28 \pm 0.33$ & $\pm 0.49 \pm 0.021$ \\
\hline & 多量 & 2 & 180 & 410 & $25 \pm 0.18$ & $\pm 0.26 \pm 0.006$ \\
\hline & 訪 & 6 & 310 & 656 & $27 \pm 0.14$ & $\pm 0.21 \pm 0.004$ \\
\hline \multirow{4}{*}{ 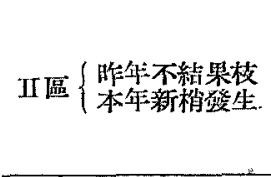 } & 少量 & 2 & 100 & 378 & $5, \quad 25 \pm 0.12$ & $\pm 0.17 \pm 0.004$ \\
\hline & 中位 & 2 & 100 & 461 & $24 \pm 0.12$ & $\pm 0.17 \pm 0.004$ \\
\hline & 多垔 & 2 & 200 & 1333 & $22 \pm 0.06$ & $\pm 0.09 \pm 0.001$ \\
\hline & 計 & 6 & 400 & 2167 & $23 \pm 0.05$ & $\pm 0.07 \pm 0.001$ \\
\hline \multirow{4}{*}{ 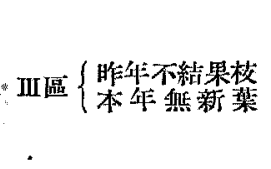 } & 少堽 & 2 & 100 & 578 & $5, \quad 23 \pm 0.06$ & $\pm 0.08 \pm 0.002$ \\
\hline & 中位 & 2 & 100 & 420 & $23 \pm 0.15$ & $\pm 0.22 \pm 0.005$ \\
\hline & 多昆 & 2 & 200 & 1429 & $22 \pm 0.05$ & $\pm 0.07 \pm 0.001$ \\
\hline & 棓 & 6 & 400 & 2426 & $23 \pm 0.04$ & $\pm 0.05 \pm 0.001$ \\
\hline
\end{tabular}

結果枝を母枝としれ花の開花日は他に比べて偏差が大であり，不揃である。

結果枝が再着花せる場合の結實步合に關する成績は第 12 表の如くである。本調查は開花 調查を行つを花に就て行つたのであるが，昨年の不結果枝で本年新笨を代ふ新梢が發生して 居る母枝は 398 枝で，2158 花中，9月 29 日には母枝賞り $69 \%$ ，花當り19\%加留り，11 
第 12 表 溫州留梢再着化枝の結寒步合

(㖹和 16 年)

\begin{tabular}{|c|c|c|c|c|c|c|c|c|c|c|c|c|c|}
\hline \multirow{3}{*}{ 膒 } & \multirow{3}{*}{ 别 } & \multirow{3}{*}{ 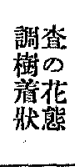 } & \multirow{3}{*}{ 㙌查 } & \multirow{3}{*}{$\begin{array}{l}\text { 謨查 } \\
\text { 校数 }\end{array}$} & \multirow{3}{*}{$\begin{array}{l}\text { 偝查 } \\
\text { 批数 }\end{array}$} & \multicolumn{4}{|c|}{9 月 29 日調 } & \multicolumn{4}{|c|}{11 月 29 日嗬 } \\
\hline & & & & & & \multicolumn{2}{|c|}{ 絬话枝 } & \multicolumn{2}{|c|}{ 絬 蜪 果 } & \multicolumn{2}{|c|}{ 絬埧校 } & \multicolumn{2}{|c|}{ 結熼果 } \\
\hline & & & & & & 數 & 率 & 數 & 輩 & 數 & ，慗， & 数 & 踣 \\
\hline \multirow{4}{*}{ I l } & \multirow{4}{*}{ 昨年結果校 } & 少量 & 2 & 63 & 116 & 22 & 35 & 24 & 21 & $\backslash 19$ & 30 & 21 & $\begin{array}{l}\% / 6 \\
18\end{array}$ \\
\hline & & 中位 & 2 & 62 & 118 & 21 & 34 & 25 & 21 & 12 & 19 & 13 & 11 \\
\hline & & 多基 & 2 & 180 & 405 & 38 & 21 & 50 & 12 & 34 & 19 & 42 & 10 \\
\hline & & 竐 & 6 & 305 & 630 & 81 & 27 & 99 & 15 & 65 & 21 & 76 & 12 \\
\hline \multirow{4}{*}{ II區 } & \multirow{4}{*}{$\begin{array}{l}\text { 晵年禾緭果校 } \\
\text { 本年新梢發坐 }\end{array}$} & 少量 & 2 & 100 & 376 & 80 & 80 & 139 & 37 & 69 & 69 & 121 & 32 \\
\hline & & 中位 & 2 & 99 & $\cdot 454$ & 78 & 79 & 119 & 26 . & 66 & 67 & 106 & 23 \\
\hline & & 多㩆 & 2 & 199 & 1328 & 116 & 58 & 161 & 12 & 99 & 50 & 136 & $10^{\circ}$ \\
\hline & & 計 & 6 & 398 & 2158 & 274 & 69 & 419 & 19 & 234 & 59 & 363 & 17 \\
\hline \multirow{4}{*}{ III 原. } & \multirow{4}{*}{ 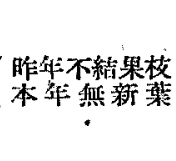 } & 少量 & 2 & 100 & 573 & 63 & 63 & 100 & 17 & 55 & 55 & 85 & 15 \\
\hline & & 中位 & 2 & 97 & 417 & 59 & 61 & 80 & 19 & 49 & 51 & 64 & 15 \\
\hline & & 多量 & 2 & 198 & 1411 & 79 & 40 & 96 & 7 & 66 & 33 & 80 & 6 \\
\hline & & 部 & 6 & 395 & 2401 & 201 & 51 & 276 & 11 & 170 & 43 & 229 & 10 \\
\hline
\end{tabular}

月 29 日には母枝當り $59 \%$. 花當り $17 \%$ であり，前年の不結果枝で本年新葉が發生して居 ない母枝は 395 枝で，2401 花中，9月 29 日には母枝當り $51 \%$ ，花當り $11 \%$ 留り，11.月

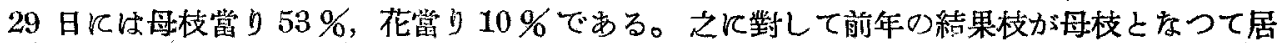

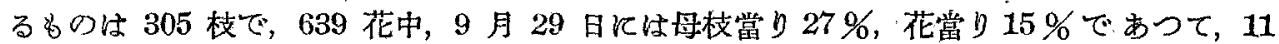
月 29 日に红母枝賞り $29 \%$ ，花當り $12 \%$ である。

即ち花當りの留り步合は前年の結果枝を母枝とした花も不結果枝学母枝としれ花も大差は

第 13 表 温州篮柑再結果枝の果梄重量（昭和 16 年 11 月）

\begin{tabular}{|c|c|c|c|c|c|}
\hline 遌 & 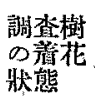 & $\begin{array}{l}\text { 調 查 } \\
\text { 铸 数 }\end{array}$ & $\begin{array}{l}\text { 偝查 } \\
\text { 枝 数 }\end{array}$ & $\begin{array}{l}\text { 圽查 } \\
\text { 果 數 }\end{array}$ & 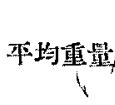 \\
\hline \multirow{4}{*}{ 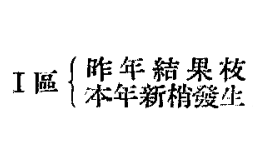 } & 少战 & 2 & 19 & 21 & 101 \\
\hline & 中位 & 2 & 12 & 13 & 109 \\
\hline & 多量卒 & 2 & 34 & 42 & 83 \\
\hline & 鼓 & 6 & 65 & 76 & $94 \pm 1.7$ \\
\hline \multirow{4}{*}{ II㾔 $\left\{\begin{array}{l}\text { 昨年不結果枝 } \\
\text { 本年棓梢猚生 }\end{array}\right.$} & 少量 & 2 & 69 & 121 & 98 \\
\hline & 中位 & 2 & 66 & 106 & 100 \\
\hline & 多量 & 2 & 99 & 136 & 84 \\
\hline & 针 & 6 & 234 & 363 & $94 \pm 0.8$ \\
\hline \multirow{4}{*}{ 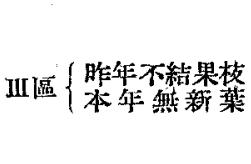 } & 少量 & 2 & 55 & 85 & 79 \\
\hline & 中位 & 2 & 49 & 64 & 75 \\
\hline & 多量 & 2 & 66 & 80 & 69 \\
\hline & 部 & $b$ & 170 & 229 & $75 \pm 0.6$ \\
\hline
\end{tabular}

なく，不結果枝の新梢發生 區之無新葉區上の中間であ るが，母枝當りの留り步合 は結果枝の方が可成り劣つ て居る。此の事讴昨年の不 䋨果枝は早枝當りで胃る上 結果伎よりも結實步合が良 いのであるが，不結果枝の 方か㴽果枝より为1本の母 枝加多數の花加脃レてb 其の留る量には太差がな く，共に大部分が 1 果で， 2-3 果留るものは僅だか らである。郎ち1枝當り の花數は絈果枝は 2.1 花飞 對して，不結果枝的新梢發 
生區の方が 5.4 花, 無新葉區で 6.1 花であり, 可成りの差があるのであるが, 果實は結果枝 は 9 月 29 日及 11 月 29 日共に 1.2 個平均に留つて居るのに對しで, 不絬果枝は新梢發

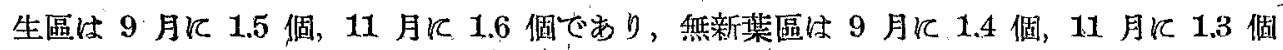
で, 三者共 1 果宛のものが大部分で，而も大差はない。

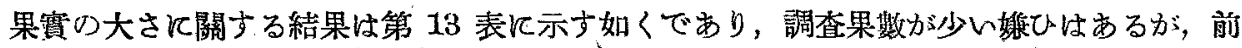
年の不結果枝を母枝としたものは新梢發生區は 1 果平均 94 瓦，無新葉區は 75 瓦であり，

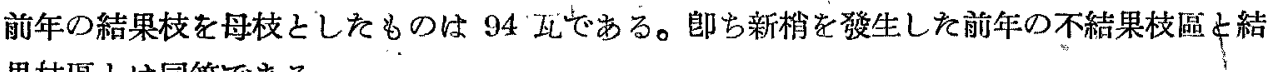
果枝區とは同等である。

\section{6. 線 合 考察}

以上の實驗並に調査成績を考察する之，柑杼の結果枝は探收に際して二度切りしたり或は 短截するよりは，果梗部で果實を探收し其儘放任して置いれ方が，明に多數の且つ長大な新 梢を發生する。郎ち新梢の全本均でも短截しをものよりは放任して置いれ方が我分長大京傾 向が有るが，2 茅短截區が發生し得る本均新梢數よりも稍多认數である所の，2 本宛の最大 新梢を放任區の各結果枝から選拔して比較すると明確に放任區の方が長大な新梢を哞生する 事か制る。及短截すると不發芽に終つそり或は枯死する割合多多く, 新梢數は放任區に比べ て明に少い。刀短截するにしても2 芽殘して切るよりは，4第索殘して切われ方が新梢數及 大さ共任れて居る。此の事は結果枝中節數（芽數）多いもの程發生する新梢數が多いと云 ふ別の實驗結果と多一致して居る。

舊梢に迄短截すると前年度の結果枝の部分で短截したよりも一層新梢數及其の大さ共に劣

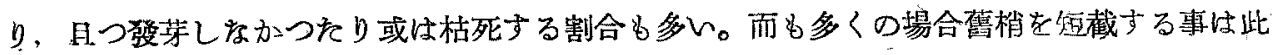
の新斷された部分には多數の結果枝群があるから，舊梢短截區け他の數枝分と比較すべきで あつて，斯くすると一層顯著に劣る事少想像される。

'不結果枝郎ち翌年に結果母枝となるい゙を枝を短截すると，結果枝を短截したるりも一層新 梢の發生數及其の大さ共に劣る。

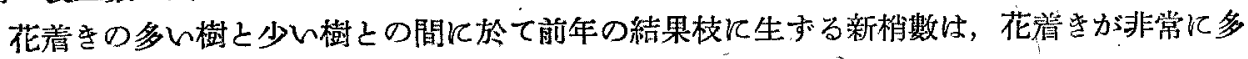
い樹は新梢の發生數の幾分か性少いが大差ではなく，花着きが中位以下のものは殆ど同樣で ある。要するに隔年絬果性の少い樹で汁大差がない樣に思はれる。但し隔年結果の甚だしい

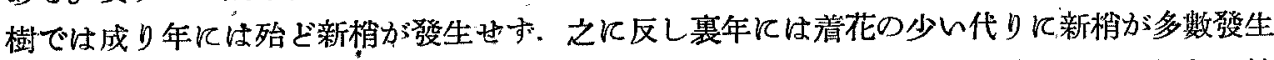
し，夏秋梢迄も發生する狀態の樹を多く見掛り゙るのであるが，か」る極端な樹で㤌前年の結 果枝に發生する新梢數にも亦可成りの差か有るのであら5事は想像するに難くない。

結果枝の長短之新梢數之の關係は，明に茅數の多い結果枝程之から發生する新梢の數が多 $n_{0}$

年に依り又樹の狀態に依つて可成りの差はあるが，鬼に角結果枝の或物は翌年再び着花，

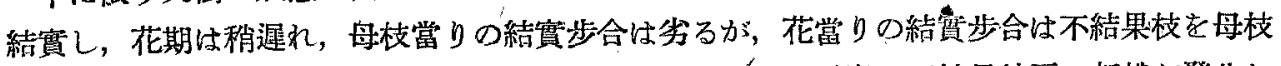
とした花の內有新梢と無新葉區との中間に位し，結實した果實は不結果枝區の新梢办發生し そものとは大差がるく，新葉のない母枝上の果實よりは大である。

前年度の結果枝が再着花する量は，本調查では溫州蜜柑は少い樹で $8 \%$, 多い樹では $60 \%$ ， ワシントン・ネーブル・オレンヂは 6-8％だが，隔年結果性の强い樹では年に依る差が二層 
著㬎であらら事岋想像される。

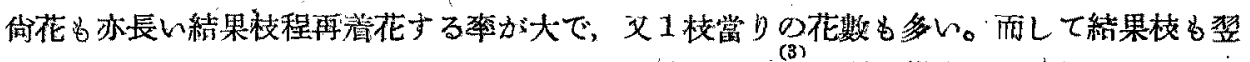

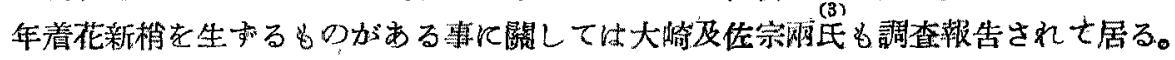

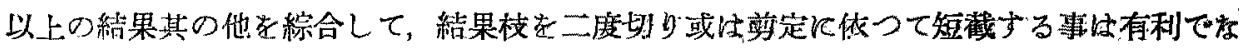

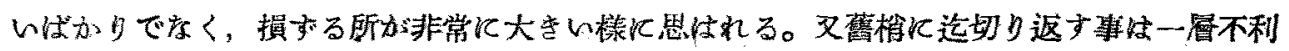
の樣飞思注れる。郎ら。

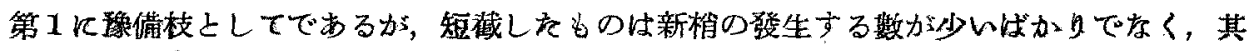

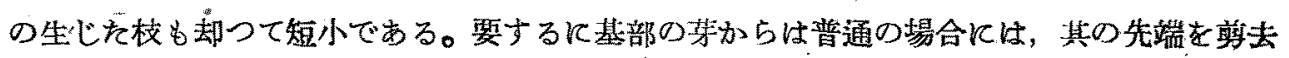
しても抬先端から生する樣度長大な枝は發生し難い樣である。

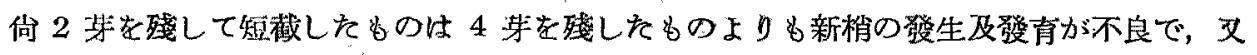
結果枝の長いもの程發生する新梢數が多い事から見て, 探收の便宜上二度切りを行ひ度い場 合で为成る可く結果枝を長く殘す樣心掛りる事が望ましい。

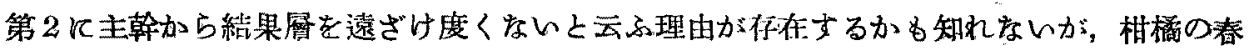

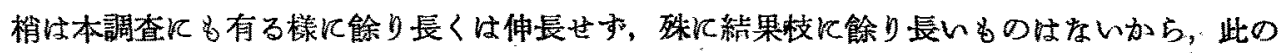

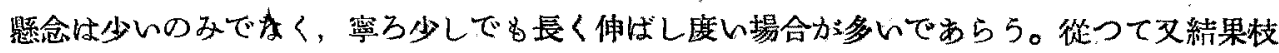

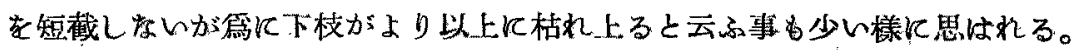

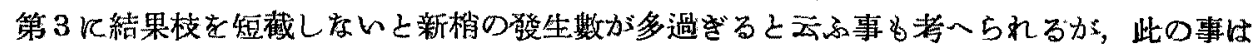

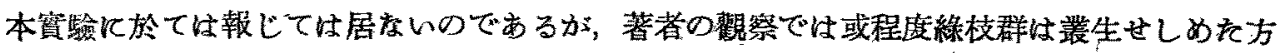
が，1 樹當りの葉面積を大ならしめ得る事其の他の临，樹勢を旺盛ならしめる樣に思ふ。

第 4 亿果梗部で果實克採收しれものは，發生する新梢が二度切りをして短截しをものより も長短大小不揃でするが，之の事は決して不利な現象ではなく，著者の觀察では，次年に一

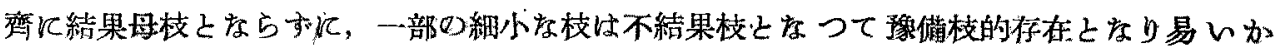

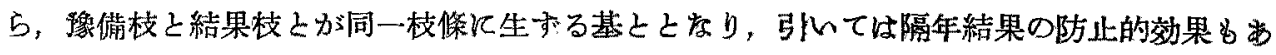
るもの上想像せられる。

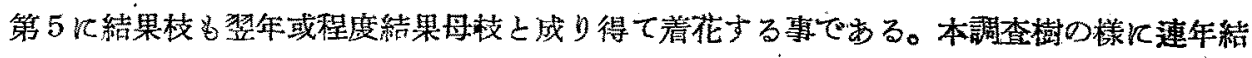
果して居る樹では，可成りの量が次々上連繶着花，結實する事に依つて，隔年結果の現象衣

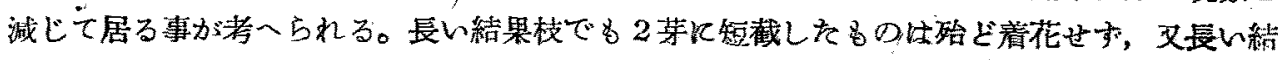
果枝程再着花する爽及量が多い事を教へる上，少しでも短截士る事は損の樣である。

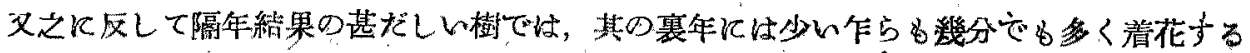

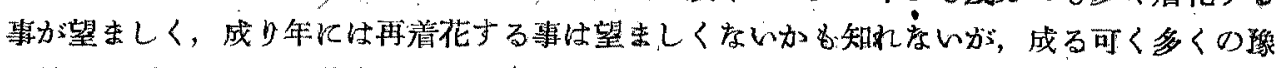

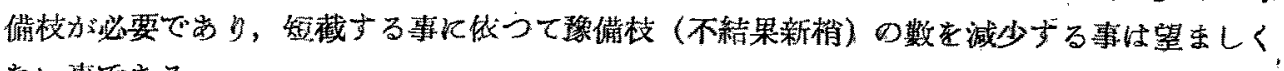
ない事である。

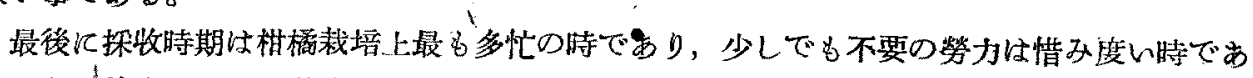
る。冬季愬是の機に型截するにしても斯く細部の剪定は可成りの勞力を要する事は諭を待て

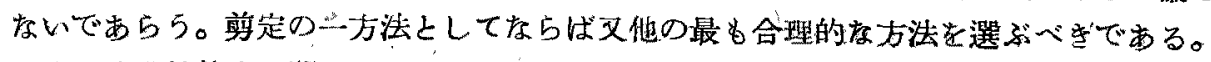

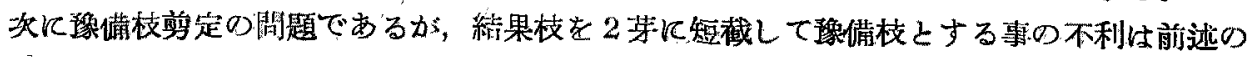

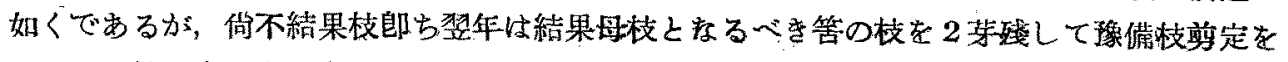

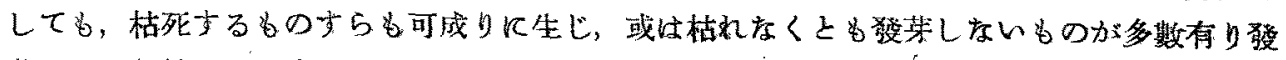

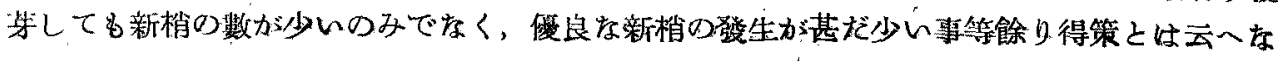


no

又舊梢に迄切り返しても不結果枝を短截しを場合と同樣，或は夫れ以上に成績不良で餘り 良豫備枝之はなり得ない。

されば豫備枝的剪定は柑橘に於ては特殊の場合を除いては佥ずる所がないばかりでなく， 損ずる所が大の盖に思ふ。されば豫備枝しして壮果實探收に際して，果梗部で探收し結果枝

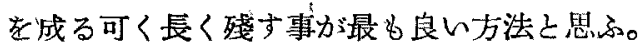

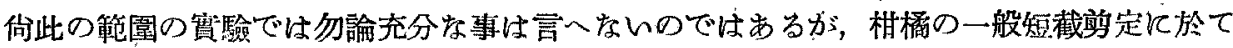
も亦，之と略類似の損失を受ける場合も有るではなから5かと思はれる。

\section{7. 摘要}

“昭和 14-17 年飞亘り，園藝試驗場傾科地及本地の溫州蜜柑樹及ワシントン・ネーブル・オ

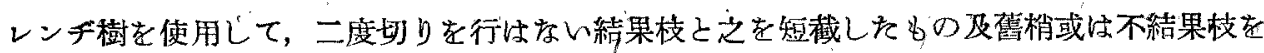
短㵶しを場合に於りる新梢の發生狀態を調查し，页前年度の結果枝に再着花する量に就て調 查した。其の結果は次の樣である。

1. 溫州蜜柑の結果枝は二度切り或は短截するよりは，果梗部で果賓を探收した方か新梢 の發生する數が多く，大小不揃であるが其の大なるものは勿論全本均に於ても長大である。

2. 舊梢又は不結果枝を短截したものは，枯死或は不發芽に終るもの多く，一層新梢の發 生不良で, 且つ生じそ新梢は短小である。

3. 結果枝が㫘年になつて發生する新梢の數は, 連年結果して居る樹では, 花着をの谌だ 多い樹は幾分少いが，大差牥をく，花着きの中位以下のもの治ど闰樣である。

4. 結果枝は其の長いもの程新梢を㻐生する數が多い。

5. 結果枝は翌年或程度再び着花枝学生する。而して其の割合は年に依り，或性樹勢反依 つて非常に差異があり，本調查で怯溫州蜜柑は 8一60\%, ワシントン・ネブル・オレンヂは 3-6\%である。

6. 長い綜果枝程翌年に着花する來が多く，且つ夫等の枝の花の數も多い。

7. 前年の結果枝を母枝としを花蕾怯，開花が不齊で且つ本均 3-4 日遲れて昖き，“新梢 を件つて居る普通の花に比べると結果率柱劣るが，果寝の大さは大差なく，新葉を件はな 花とは母枝當りの結果率はやはり劣るが，花當りの結果率は却つて稍偼り，果實为大である。

8. 以上を綜合考案して結果枝は二度切り或は其の他几依つて然截する事は, 益をく, 損 ずる所が大でする樣に思はれる。

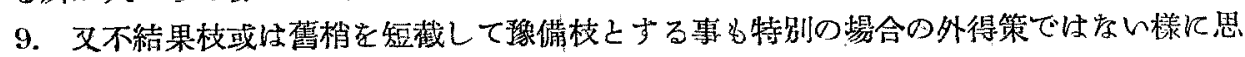
梳扎る。

\section{8. 引用文獻}

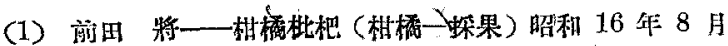

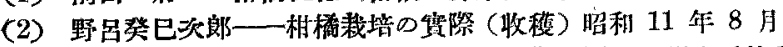

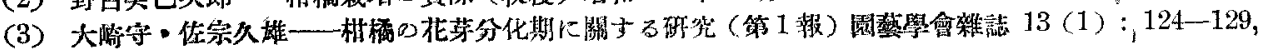
炤和 17 年 3 月

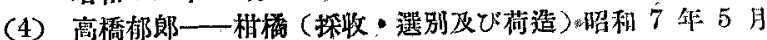

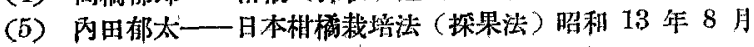

